\title{
Flow regime of the Lambert Glacier-Amery Ice Shelf system, Antarctica: structural evidence from Landsat imagery
}

\author{
Michael J. HAMBrey \\ School of Biological and Earth Sciences, Liverpool John Moores University, Liverpool L3 $3 A$ F, England \\ JULIAN A. DOWDESWELL \\ Scott Polar Research Institute, University of Cambridge, Cambridge CB2 1ER, England
}

\begin{abstract}
High-resolution visible and near-infrared satellite imagery provides a means of investigating the structural glaciology, and in turn the dynamics, of large ice masses. The Lambert Glacier-Amery Ice Shelf system is one of the largest ice drainage basins in Antarctica and has previously yielded conflicting evidence concerning its dynamic behaviour: either that the system has a propensity for surging or that it has a constant flow regime. Digital manipulation of Landsat imagery allows analysis of the structure of the glacier system, showing longitudinal foliation, medial moraines and crevasse patterns that provide no evidence of surging behaviour during the residence time of ice in the glacier system.
\end{abstract}

\section{INTRODUGTION}

The possibility of disintegration of large parts of the Antarctic ice sheet, either through the removal of ice shelves (which hold back the marine-based West Antarctic ice sheet) under the influence of global warming or as a result of surging of the major ice drainage basins, has been suggested on a number of occasions (Wilson, 1964; Hollin, 1969; Hughes, 1975; Mercer, 1978). Supporting evidence of surging has been offered for the Lambert Glacier-Amery Ice Shelf system (Fig. 1), which drains about one-fifth of the East Antarctic ice sheet (Budd and McInnes, 1978; Derbyshire and Petersen, 1978; Allison, 1979; Wellman, 1982). However, other authors have argued against surging for this system (Robin, 1979, 1983; McIntyre, 1985a; Radok and others, 1987).

The purpose of this paper is to examine the structural evolution of the Lambert Glacier-Amery Ice Shelf system in order to assess whether the system exhibits surging on a cyclical basis or has a constant flow regime. Features such as foliation, medial moraines and crevasse patterns, observable in Landsat images, may be used to determine the mode of flow of the major ice streams and outlet glaciers of the Antarctic ice sheet. These structures are most obvious where the snow cover has been removed by ablation, revealing bare glacier ice, as in the case of the Lambert Glacicr system. These structures are described from an analysis of digital Landsat imagery and are discussed in the context of possible past instabilities in the flow of the system.

\section{THE LAMBERT GLACIER-AMERY IGE SHELF SYSTEM}

The Lambert Glacier-Amery Ice Shelf system is a composite feature, comprising eight structurally defined ice streams, for example, Lambert, Mellor and Fisher Glaciers, which feed into the Amery Ice Shelf (Figs 2 and 3). A number of other ice streams join the main trunk glacier along its length, notably Charybdis Glacier from the west, and a large ice stream off Mawson Escarpment from the east (Fig. 1). Data on ice thickness, velocity, ice discharge and the grounding-line position have been provided by Morgan and Budd (1975), Budd and others (1982), McIntyre (1985a) and Hambrey (1991).

A model of surging of the system (Budd and others, 1978) suggested a surge periodicity of the Lambert Glacier-Amery Ice Shelf system of 23000 years, with major. surges lasting 250 years and velocities reaching several kilometres per year. It was further suggested that similar behaviour might be representative of other Antarctic drainage basins.

Allison (1979) calculated the state of balance of the system from mass-balance and ice-flux data, and found that the mass flux for the interior part of the Lambert Glacier basin was far in excess of output into the main channel of Lambert Glacier. He regarded this imbalance as providing evidence for the build-up of ice prior to a surge. On the other hand, Robin $(1979,1983)$ reached the alternative conclusion that the apparent imbalance may be due to strong basal melting. In a re-assessment of the area of the interior basin from Landsat imagery, McIntyre (1985a) reduced its size from 1.09 to 0.90 


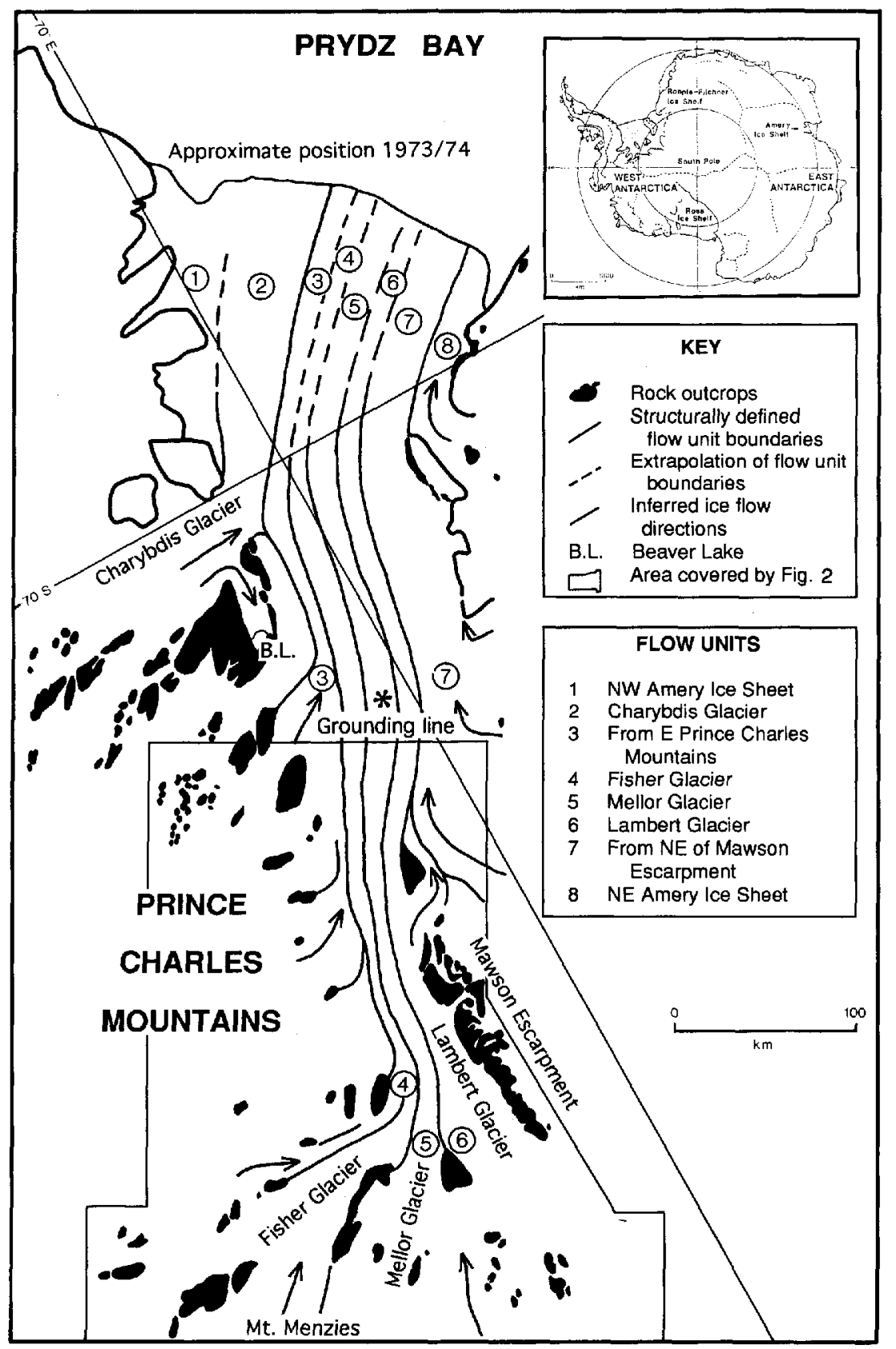

I ïg. 1. Major flow units of the Lamben Glacier-Amery Ice Shelf system devived from the structural pattern revealed in satellite images (after Hambrey, 1991). The grounding line is from Budd and others (1982). The localion of Figure 2 is shown. The location of the Lambert Glacier-Amery Ice Shelf system within Anlarctica is shown in the inset; dashed lines represent ice divides (after Drexury, 1983).

$\times 10^{6} \mathrm{~km}^{2}$, and further suggested that the accumulation rate was much lower than previously estimated; this had the effect of reducing the mass flux from the interior basin to a figure that almost matched the input into Lambert Glacier. Subsequent correspondence (Allison and others, 1985; McIntyre, 1985b) served to emphasizc the disagreement and pointed to a need for better field data, especially concerning accumulation rates, or for alternative methods of analysis.

Most recently, an attempt has been made using a thcoretical modelling approach to determine which Antarctic drainage basins were prone to surging (Radok and others, 1987). The models demonstrated that the major Antarctic ice streams, including the Lambert Glacier-Amery Ice Shelf system, are unlikely to surge.

\section{METHODS}

Enhancement of digital satellite imagery allows specific surface features relating to structure and topography to be analysed in detail (cf. Dowdeswcll and McIntyre, 1987). Digital data from three Landsat Multispectral Scanner (MSS) scenes, covering the four spectral bands with wavelengths between 0.5 and $1.1 \mu \mathrm{m}$ (path/row $134 / 112$ imaged on 20 February 1974; path/row $135 / 111$ and 135/ 112 , both imaged on 16 March 1973), were manipulated on a Sun-based image-processing system in Cambridge, and structural analysis took place on enhanced images both on screen and in the form of hard copy.

In the absence of measurements of velocity and strain rate, the pattern of ice structures may be used to infer flow 


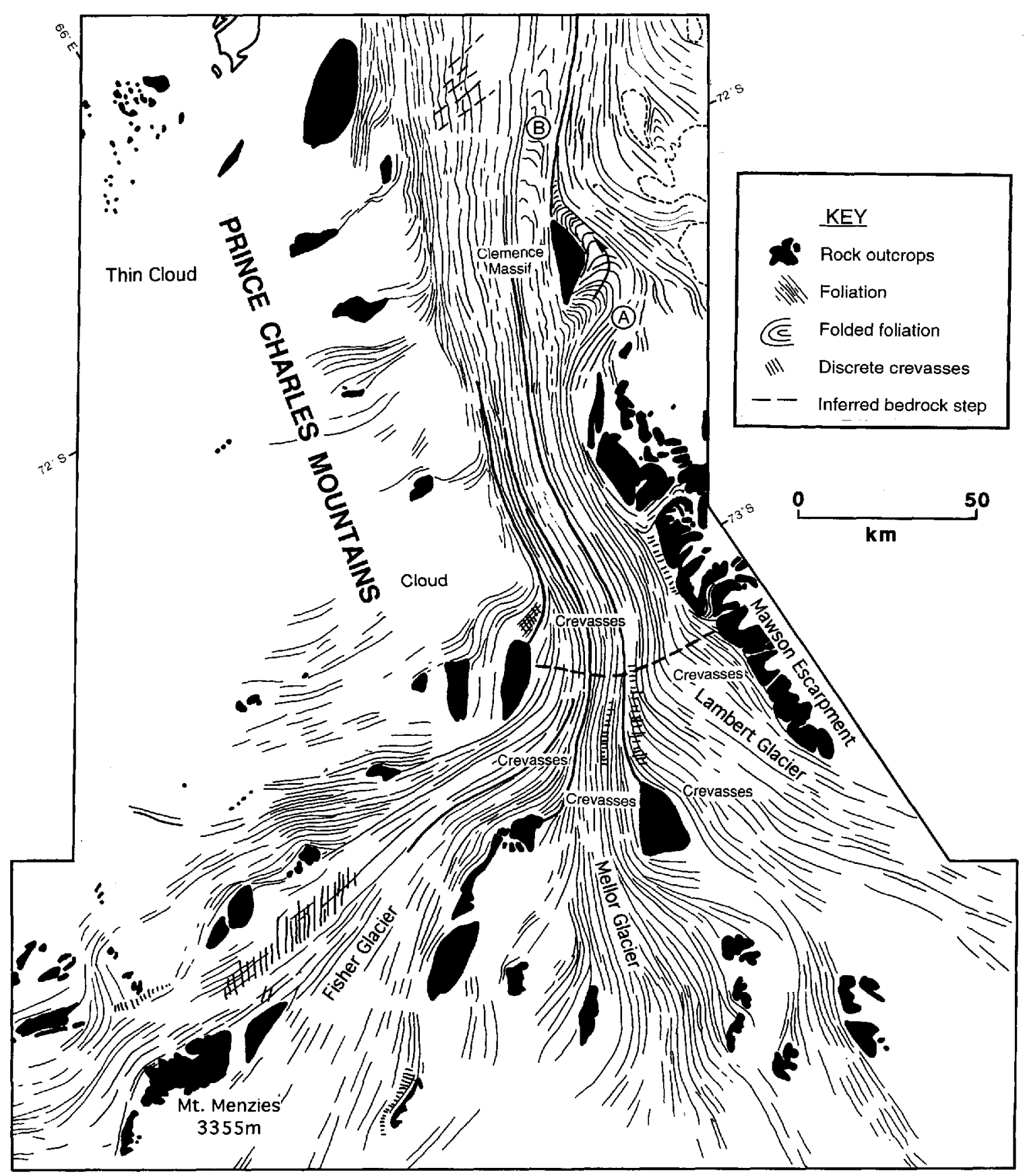

Fig. 2. Sinuclural map from satellite imagery, illustrating the dominant foliation trend, medial moraines and discernible crevasse patterns in the region where Lambert, Mellor and Fisher Glaciers merge.

dynamics and particle paths through icc masses (Reynolds, 1988; Reynolds and Hambrey, 1988; Hambrey, 1991). Despite the order-of-magnitude larger scale, there is a close correspondence between the crevasse and foliation patterns in large ice streams, such as the Lambert Glacier system, and those in valley glaciers in mountain regions ( $c$. Hambrey and Müller, 1978).

Landsat images, which clearly depict the major structures, cover Lambert, Mellor and Fisher Glaciers, and the main Lambert Glacier system north of the confluence of these ice streams (Fig. 1), areas which arc critical for examining structural evidence for a variable how regime. Satellite imagery is probably recording both the gross tcxtural contrasts between different flow units and topographic variations. Dowdeswell and McIntyre (1987) have shown, through comparison of Landsat imagery and airborne altimetric data from the head of Byrd Glacier, that the surface expression of foliation may. have amplitudes in excess of $10 \mathrm{~m}$.

\section{STRUCTURE OF LAMBERT GLACIER AND ITS TRIBUTARIES}

\section{Foliation}

The dominant feature on digitally enhanced Landsat imagery of the Lambert Glacier Amery Ice Shelf system is a longitudinal structure or foliation (Fig. 2). Such structures, which in Antarctic ice masses generally are parallel to the margins of the flow unit, have previously been referred to as flowlines Crabtree and Doake, 1980; Swithinbank, 1988), 


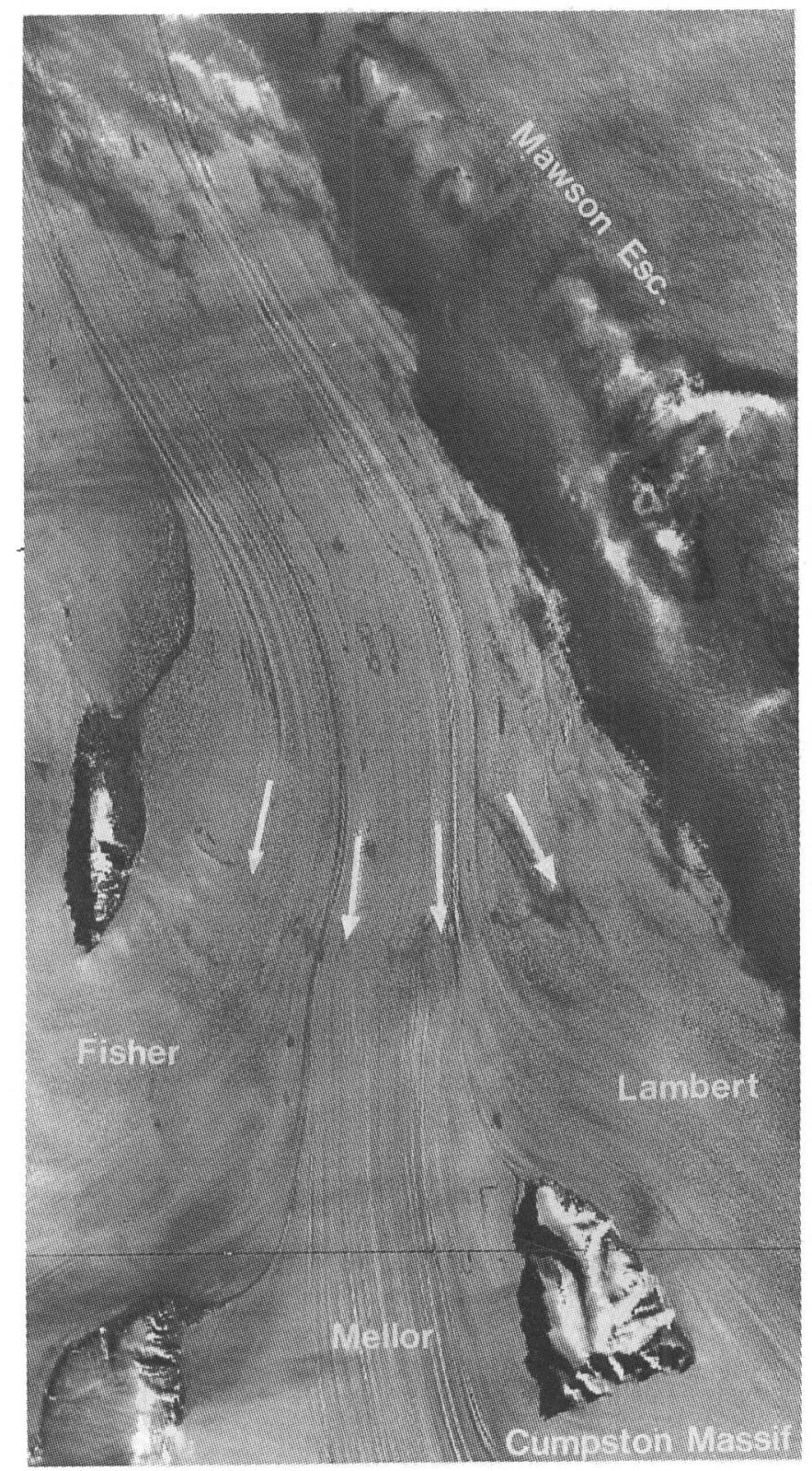

Fig. 3. Digitally enhanced Landsat MSS image of the confluence region of Lambert, Mellor and Fisher Glaciers. The image is from pathirow 134/112, acquired on 20 February 1974 , and is approximately $70 \mathrm{~km}$ across. A maked break of slope, seaward of the confluence and approximately $70 \mathrm{~km}$ across, is marked by arrows. Ice flow in the main channel is towards the north-northeast, i.e. the top of the image.

flow stripes of uncertain origin (Casassa and others, 1991) or flow traces originating from former shear margins (Merry and Whillans, 1993). However, the structures are not always parallel to current flow direction and, from ground observations elsewhere, it appears that they are the surface expression of the threc-dimensional structure, longitudinal foliation Reynolds and Hambrey, 1988). Longitudinal foliation commonly is parallel to medial moraines and is therefore uscful in delincating individual flow units.

In the Lambert Glacier-Amery Ice Shelf system, the foliation and moraine pattern indicate that, as flow units merge, their width is considerably reduced (Figs 13 ) and the foliation is intensified.

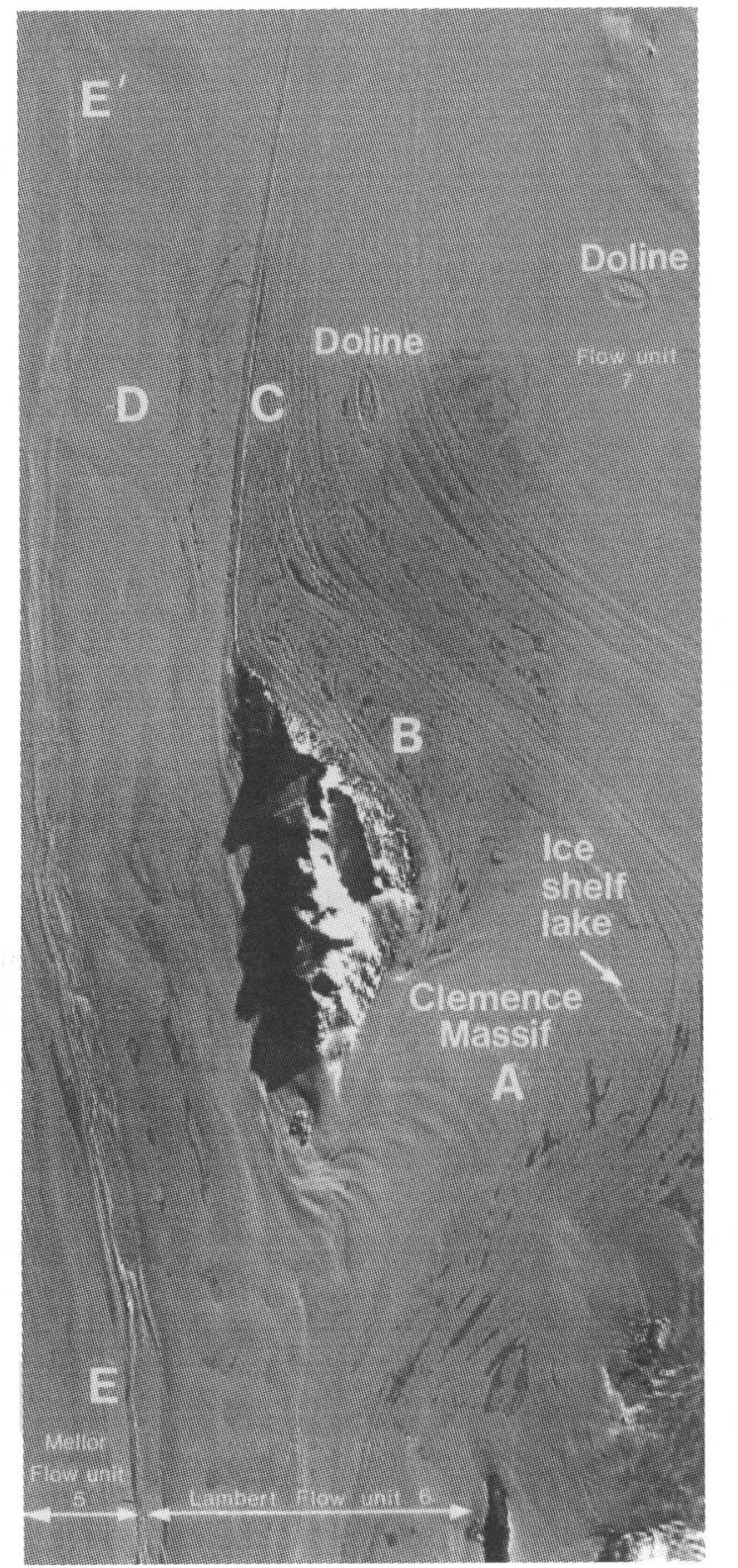

Fig. 4. Digitally enhanced Landsat MSS image of ice flowe around Clemence Massif, located in Figure 1. The image is from pathlrow 135/111, acquired on 16 March 1974 , and is approximately $40 \mathrm{~km}$ across. Ice flow is towards the north-northeast (top of image) in the zone to the left of Clemence Massif. Various features are labelled and discussed in the text.

Although the foliation remains parallel to the overall direction of flow, diverging flow around Clemence Massif to the north of Mawson Escarpment (Fig. 1) deforms the longitudinal foliation into an arcuate or transverse trend as it turns northeast and flows around the eastern side of this nunatak Fig. 4. Initially, the arcs are expressed at the surface as waves a few kilometres apart (Fig. 4. location A). After passing through a snow-covered area showing relatively little definition, this ice turns northwest and the arcs, now as 1ransverse foliation, re-emerge. The arcs bccome progressively tighter downstream as icc flow is constrained by a major ice stream (flow unit 7). The structure here is clearly picked out by meltpools on the ice 
surface (Fig. 4, location $B$ ). As the ice rejoins the main trunk glacier (Fig. 4, location C), the arcuate foliation becomes incrcasingly attenuated. Transposition of this structure to a new longitudinal foliation takes place in the zone of convergence. To the west of Clomence Massif, the longitudinal foliation of the Lambert Glacier flow unit also becomes deformed, here forming faint drag-like folds (Fig. 4, location D).

\section{Crevasses}

Crevasses are widely distributed in the three ice streams, Fisher, Mellor and Lambert, that feed into the main trunk glacier called Lambert Glacier. In the first two ice streams, longitudinal zones of closcly spaced transverse crevasses several kilometres wide are separated by relatively crevasse-free zones of similar width (Fig. 3). 'These zones are parallel to the dominant longitudinal structure and are present across the entire width of each ice stream. In Lambert ice stream, crevasse fields are more extensive and chaotic, and the zones, although still recognizable in enhanced images, are more diffuse.

Soon after the three ice streams have merged, the ice passes through a transverse, concave down-glacier zone of disturbed flow (arrowed in Figure 3). Here, the crevasses are locally more intense and the longitudinal structures are slightly bent. These perturbations are probably related to a bedrock step or riegel and the ice surface has the appearance of steepening through this zone.

Down-glacier, the crevasses gradually die out and, as the ice enters the narrowest part of the Lambert Glacier trough, few remain, allowing meltwater streams to flow considcrablc distances and lakes to form on the glacier surface. Only at the margins of the main trunk glacier, where small tributarics descend from the Prince Charles Mountains and Mawson Escarpment, are marginal crevasses developed.

\section{Boudinage}

Boudinage structures on a scale of a few metres, resulting from differences in ductility within a multi-layered sequence, are common in foliated glacier ice (Hambrey and Milnes, 1975).

The zone between the Mellor and Lambert flow units west of Clemence Massif displays a string of mega-boudins (Fig. 4, line EE'). On average, these are $2 \mathrm{~km}$ wide, thinning to $1 \mathrm{~km}$ at the necks or breaking into discrcte blocks, and are of the order of $5 \mathrm{~km}$ long. These megaboudins appear to originate to the west of Mawson Escarpment to the south, and become more pronounced adjacent to Glemence Massif. Their development is probably related to longitudinal extension of the ice, first where it becomes strongly channelized and sub-sequently as it approaches the grounding zone. Mega-boudins are also evident at the boundary between the Fisher and Mellor flow units east and northeast of Fisher Massif.

\section{Other surface features}

Grounding lines or zones are often associated with a break in ice-surface slope and have been identified in a number of places around Antarctica (e.g. Swithinbank, 1988).
Several ice-surface features, exhibited on enhanced Landsat imagery of the area around Clemence Massif (Fig. 4), suggest that the ice may be afloat at this location, considerably further south of the grounding-line position of Budd and others (1982). These features (Fig. 4) include: (i) a very flat feature about $6 \mathrm{~km}$ in length occupying a depression and having the form of an icecovered lake, which may bc connected to sub-ice-shelf waters; (ii) two elliptical depressions $3-4 \mathrm{~km}$ in diameter, similar to features termed "ice dolines" by Mellor (1960) and found on several Antarctic ice shelves (Mellor and McKinnon, 1960; Swithinbank, 1988); these features have been interpreted as melt lakes that drain periodically through fractures to the sea beneath (Swithinbank, 1988); (iii) large areas of icc-surface lakes, indicating the very low ice-surface slopes found in this area. Floating ice around Glemence Massif would imply that the ice shelf extends at least $400 \mathrm{~km}$ inland from the terminus of the Amery Ice Shelf on the east side of Lambert Glacier.

\section{DISGUSSION}

\section{Does the Lambert Glacier-Amery Ice Shelf system surge?}

Structural patterns in surge-type glacier systems are distinctive and differ from those in glacicrs of the nonsurging type (Meier and Post, 1969; Post, 1972). Folded and truncated foliation, and tear-drop-shaped moraines are typical. If the Lambert Glacier system, and in particular Fisher Glacier, had surged as previously supposed (Wellman, 1982) within the time it takes for all its ice to reach the ice-shell edge, surge-related structures should be clcarly visible in the satellite imagery. Evidence of surging in earlier times would have been preserved down-glacier if any of these flow units had surgcd. Velocity data suggest a residence time of ice passing along the centre line is of the order of 1000 years, a figure likely to be an order-of-magnitude greater near the margins. None of this ice shows evidence of former surging behaviour. Rather, we conclude that the structures indicate a constant flow and constant deformation regime through time (Fig. 4).

Crevasse patterns may also be used to infer whether a glacier is building up to a surge condition. During the quiescent phase of a surge-type glacier, crevasses disappear as the ice stagnates. As the ice at the head of the glacier builds up to a new surge and becomes more active, it becomes progressively more crevassed. There is a clear demarcation between heavily crevassed ice and ice which remains relatively slow moving (Iawson, 1989). There is no such demarcation in Lambert Glacicr, further supporting the hypothesis that the flow regime is constant. This flow rcgime appears to have been maintained even though the ice thickness and mass balance may have changed considerably during this period.

\section{Implications}

The method of analysing ice structures using Landsat imagery, which has been tested alongside ground obscrvations clscwhere, has scrved to demonstrate that 
one of the major drainage basins of East Antarctica has not surged for several thousand years. In contrast, imbalances in flow have been documented for Ice Stream B, which feeds the Ross Ice Shelf from the West Antarctic ice sheet (Bindschadler and others, 1987; Whillans and others, 1987). Surging is further suggested by the deformed nature of "flow stripes" (which we interpret as foliation) in the Ross Ice Shelf (Casassa and others, 1991).

Satellite imagery offers the prospect of determining, from structural patterns, the flow regimes of many other parts of the Antarctic ice sheet, and establishing which, if any, part has a propensity for surging. In ice masses outside Antarctica, such phenomena are exceptional, and there is little reason to suppose that the Antarctic ice sheet is any different.

\section{ACKNOWLEDGEMENTS}

We thank the B. B. Roberts Fund of the Scott Polar Research Institute for the financial support which facilitated this work, and M.J. Sharp, I. M. Whillans and two anonymous referees for comments on versions of this paper.

\section{REFERENGES}

Allison, 1. 1979. The mass budget of the Lambert Glacier drainage basin, Antarcica. J. Glaciol., 22(87), 223235.

Allison, I. F., N. W. Young and 'T. Medhurst. 1985. On re-assessment of the mass balance of the Lambert Glacier dranage basin, Antaretica. f. Glaciol, 31 $(109), 378-381$.

Bindschadicr, R. A., S. N. Stephenson, D. R. MacAycal and S. Shabtaie. 1987. Ice dynamics at the mouth of Ice Stream B, Antarctica. 7. Geophys. Res., 92(B9), 8885-8894.

Budd, W.F. and B.J. McInnes. 1978. Modelling surging glaciers and periodic surging of the Antarctic ice shect. In Pittock, A. B., L. A Frakes, D. Jenssen, J.A. Peterson and J.W. Zillman, eds. Climatio change and variability: a southern perspective. Cambridge, Cambridge University Press, 228-233.

Budd, W.F., M.J. Corry and 'T. H. Jacka. 1982. Results from the Amery Ice Shalf l'roject. Amn. Glacol., 3, 36-4l.

Casassa, G., K. C. Jezek, J. Turner and 1. M. Whillans. 1991. Relict flow stripes on the Ross Ioc Shelf. Ann. Glaciol., 15, 132-138.

Crabtree, R. D. and C.S. M. Doake. 1980. Flow lines on Antarctic ice shelves. Polar Rec., 20 (124), 3137.

Dorbyshirc, E. and J. A. Peterson. 1978. A photo-geomorphic map of the Mt. Menrics nunatak, Prince Charles Mountains, Australian Antarctic l'erritory. Z. Glelscherkd. Glazialgeol., 14, 17-26.

Dowdeswell, J.A. and N. F. McIntyre. 1987. The surface topography of large icc masses from Landsat imagery. J. Glaciol., 33 1 13), 16-23.

Drewry, D.J. 1983. The surface of the Antarctic ice sheet. In Drewry, D.J., ed. Antartica: glaciological and geophysical folio. Cambridge l'niversity of Cambridge. Scrtt Polar Rescarch Institute, Shect 2.
Hambrey, M.J. 1991. Structure and dynamics of the Lambert GlacierAmery Ice Shelf system: implications for the origin of Prydz Bay sediments. In Barron, J. and others. 1991. Proceedings of the Ocean Drilling Program, Scientific Results, 119.61 75. Ocean Drilling Program, College Station, Texas.

Hambrey, M.J. and A. G. Milnes. 1975. Boudinage in glacier ice-some cxamples. 7. Glaciol., 14(72), 383-393.

Hambrey, M.J. and F. Muller. 1978. Structures and ice deformation in the White Glacier, Axel Heiberg Island, Northwest Territories, Ganada. J. Glaciol., 20/82), 41-66.

Hollin, J. T. 1969. Ice-sheet surges and the geological record. Can. J. Earth Sci., 6, 903910.

Hughes, T. 1975. The West Antarctic ice sheet: instability, disintegration, and initiation of ice ages. Rev. Geophys. Space Phys., 134), $502-526$.

Lawson, W. 1989. The structural cvolution of the Variegated Glacier, Alaska. (Ph.D. dissertation, University of Cambridge.)

McIntyre, N.F. 1985a. A re-assessment of the mass balance of the Lambert Glacier drainage basin. Antarctica. 7. Giaciol., 31 107), 34-38.

McIntyre, N. F. 1985b. Reply to "On re-assessment of the mass balance of the Lambert Glacier drainage basin, Antarctica". 7. Glaciol., $31(109), 381$.

Meicr, M.F. and A. S. Post. 1969. What are glacier surges? Can. ff. Earth Sci., 6 4), 807-817.

Mellor, M. 1960. Correspondence. Antaretic ice terminology: ice dolines. Polar Rec, $10(64), 92$.

Mellor, M. and G. McKinnon. 1960. The Amery Ice Shelf and its hinterland. Polar Rec., 10 64), 30-34.

Mercer, J.H. 1978. West Antarctic ice sheet and $\mathrm{CO}_{2}$ greenhouse effect: a threat of disaster. Nature, 271 5643$), 321-325$.

Merry, C.J. and I. M. Whillans. 1993. Ice-flow features on Ice Stream B, Antarctica, revealed by SPOT HRV imagery. J. Glaciol, 39 133), $515-527$.

Morgan, V.I. and W.F. Budd, 1975. Radio-echo sounding of the Lambert Glacier basin. J. Glaciol., 15(73), 103-111.

Post, A. 1972. Periodic surge origin of folded medial moraines on Bering Piedmont Glacier, Alatska. 7. Glaciol., 11 62), 219-226.

Radok, U.. D. Jenssen and B. McInnes. 1987. On the surging potential of polar ice streams. Antartic surges - a clear and present danger. Washington. DC. U.S. Department of Energy. (DOE/ER/60197-H1.)

Reynolds, J.M. 1988. The structure of Wordie Ice Shelf, Antarctic Peninsula. Brit. Antart. Surv, Bull., 80, 5764.

Reynolds, J. M. and M.J. Hambrey. 1988. The structural glaciology of Grorge VI Ice Shell, Antarctica. Brit. Antarct. Surc. Bull., 79. 79-95.

Robin, G. de Q. 1979. Formation, flow and disintegration of ice shelves. J. Glaciol., 24(90), 259271.

Robin, G.de Q. 1983. Coastal sites, Antarctica. In Robin, G.de Q., ed. The climatic record in polar ice sheets. Cambridge, Cambridge University Press, 118122.

Swithinbank, C. 1988. Satcllitc image atlas of glaciers of the world. Antarctica. Li.S. Geol. Surv. Prof. Pap. 1386-B, 1-138.

Wellman, P. 1982. Surging of Fisher Glacier, Fast Antarctica: cvidence from geomorphology. 7. Glaciol. 28(98), 2328.

Whillans, I. M., J. Bolzan and S. Shabtaic. 1987. Velocity of Ice Streams B and C, Antarctica. J. Geophys. Res., 92 B9), 8895-8902.

Wilson, A. T. 1964. Origin of ice ages: an ice shelf theory for Plcistocene glaciation. Nature, 201 (4915), 147-149

The accuracy of references in the text and in this list is the responsibility of the authors, to whom queries should be addressed. 